\title{
Celiac Disease and Glandular Autoimmunity
}

\author{
George J. Kahaly ${ }^{1, *}$, Lara Frommer ${ }^{1}$ and Detlef Schuppan ${ }^{2,3}$ \\ 1 Department of Medicine I, Johannes Gutenberg University (JGU) Medical Center, 55101 Mainz, Germany; \\ Lara.Frommer@unimedizin-mainz.de \\ 2 Institute for Translational Immunology and Research Center for Immunotherapy (FZI), Johannes Gutenberg \\ University (JGU) Medical Center, 55101 Mainz, Germany; Detlef.Schuppan@unimedizin-mainz.de \\ 3 Division of Gastroenterology, Beth Israel Deaconess Medical Center, Harvard Medical School, \\ Boston, MA 02215, USA \\ * Correspondence: george.kahaly@unimedizin-mainz.de; Tel.: +49-6131-17-2290
}

Received: 6 June 2018; Accepted: 21 June 2018; Published: 25 June 2018

\begin{abstract}
Celiac disease is a small intestinal inflammatory disease with autoimmune features that is triggered and maintained by the ingestion of the storage proteins (gluten) of wheat, barley, and rye. Prevalence of celiac disease is increased in patients with mono- and/or polyglandular autoimmunity and their relatives. We have reviewed the current and pertinent literature that addresses the close association between celiac disease and endocrine autoimmunity. The close relationship between celiac disease and glandular autoimmunity can be largely explained by sharing of a common genetic background. Further, between 10 and $30 \%$ of patients with celiac disease are thyroid and/or type 1 diabetes antibody positive, while around $5-7 \%$ of patients with autoimmune thyroid disease, type 1 diabetes, and / or polyglandular autoimmunity are IgA anti-tissue transglutaminase antibody positive. While a gluten free diet does not reverse glandular autoimmunity, its early institution may delay or even prevent its first manifestation. In conclusion, this brief review highlighting the close association between celiac disease and both monoglandular and polyglandular autoimmunity, aims to underline the need for prospective studies to establish whether an early diagnosis of celiac disease and a prompt gluten-free diet may positively impact the evolution and manifestation of glandular autoimmunity.
\end{abstract}

Keywords: celiac disease; glandular autoimmunity; autoimmune thyroid disease; type 1 diabetes; polyglandular autoimmune syndrome

\section{Celiac Disease}

Celiac disease $(\mathrm{CeD})$ is defined as a life-long intolerance to dietary gluten that results in small intestinal inflammation, villous atrophy, crypt hyperplasia, and often malabsorption. The ingestion of gluten containing cereal grains, mainly wheat, rye, and barley, drives this $\mathrm{T}$ cell driven auto-destructive process within the small intestinal mucosa which usually recovers when these cereals and gluten are rigorously withdrawn from the diet [1-4].

At least $50 \%$ of $\mathrm{CeD}$ is diagnosed in adulthood, and in the majority of adolescents and adults clinical features at diagnosis are subtle, with mild abdominal discomfort, fatigue, low bone mineralisation and hypocalcaemia, and only rarely manifest anemia, weight loss, infertility, or recurrent aphtous stomatitis. However, up to one third of adults suffer from one or more CeD-associated autoimmune diseases, prominently with autoimmune thyroid disease (AITD) and type 1 diabetes mellitus (T1D), but also rheumatoid diseases including systemic lupus erythematodes, Sjoegren's syndrome, autoimmune liver diseases, and others [5]. Severe complications, like refractory CeD type 2, a premalignant condition, and overt enteropathy-associated T-cell lymphoma, occur in patients with longstanding undetected and untreated $\mathrm{CeD}$, but remain rare [6,7]. Iron, zinc, vitamin $\mathrm{D}$, vitamin $\mathrm{B} 12$, or folic acid deficiency, iron deficiency or overt anemia are the most common laboratory finding. 
Frequent episodes of hypoglycemia, a reduction of insulin requirements and brittle diabetes may indicate the presence of $\mathrm{CeD}$ in patients with T1D [8]. CeD is considered sufficiently prevalent and the benefits of diagnosis and treatment by gluten withdrawal are such that it is advocated to screen all patients with T1D (and autoimmune thyroid disease) for this disorder.

Both endoscopic-histological diagnosis and the presence of circulating $\operatorname{Ig} \mathrm{A}$ antibodies $(\mathrm{Ab})$ to tissue transglutaminase (TG2) confirm the diagnosis. As shown in Table 1, anti-transglutaminase antibodies may be of IgG isotype in the presence, but also in the absence of a selective IgA deficiency. This suggests that the gluten-triggered autoantibody response shows mucosal $\operatorname{IgA}$ as its main component, while systemic IgG may represent a long-term reaction probably related to the occurrence of extra-intestinal manifestations. Consistently, it has been reported previously that the prevalence of $\mathrm{CeD}$ in T1D increases dramatically when the detection of both IgA and IgG autoantibodies is used in the screening. After a gluten-free diet the IgA-TG2-Ab disappear in most patients with $\mathrm{CeD}$, usually with a half-life between 30 and 60 days.

Table 1. Autoimmune disease specific antibodies.

\begin{tabular}{cc}
\hline Disease & Autoantibodies \\
\hline Celiac disease & Tissue transglutaminase IgA (IgG) \\
& Glutamate decarboxylase (GAD) \\
Type 1 diabetes & Tyrosine phosphatase (IA2) \\
& Islet cell (IC) \\
& Insulin \\
& Zinc transporter (ZnT8) \\
Autoimmune thyroid disease & Thyro-peroxidase (TPO) \\
& Thyroglobulin (Tg) \\
& TSH receptor \\
\hline
\end{tabular}

Genetic factors greatly determine susceptibility to CeD. All CeD patients carry HLA DR3/DQ2 (mainly DQA1*0501-DQB1*0201; 85-95\%), or HLA DR4/DQ8 (DQA1*0301-DQB1*0302; 5-15\%), or both haplotypes [1-3]. Exceptions are certain Native American populations that mainly carry DQ8 [9]. Since, e.g., the prevalence of HLA DQ2 in most populations is between 25 and $50 \%$, only a minority with this necessary but insufficient genetic predisposition will ever develop CeD. This implies the involvement of additional, non-HLA linked genes, as well as environmental factors in CeD manifestation, as discussed below.

The ubiquitous enzyme TG2, the $\mathrm{CeD}$ autoantigen, is central to the pathogenesis of $\mathrm{CeD}$, since it can deamidate specific glutamine residues in certain gluten peptides that remain undigested and reach the subepithelial small intestinal lamina propria. This deamidation of the gluten peptides and their haptenization by binding to TG2 itself (autocatalysis) thereby increases their affinity to DQ2 or DQ8 on professional antigen presenting cells like macrophages, dendritic, and B cells, favoring the subsequent gluten specific destructive T cell response [1,10-12].

\section{Monoglandular and Polyglandular Autoimmunity}

Patients with $\mathrm{CeD}$ show a high prevalence of glandular autoimmune disorders [13-16]. CeD is associated with T1D, AITD i.e., Hashimoto's thyroiditis (HT), Graves' disease (GD), and the polyglandular autoimmune syndrome (PAS) [17].

\subsection{Type 1 Diabetes}

T1D is a T-cell mediated glandular autoimmune disease that develops in genetically susceptible individuals and results in destruction of the insulin-producing $\beta$ cells. Of T1D patients, $15-30 \%$ have AITD and 3-12\% present with CeD [18]. The close relationship between CeD and glandular autoimmunity can be widely explained by sharing of a common genetic background. However, 
some common pathogenic mechanisms have been further implicated, such as increased intestinal permeability resulting from zonulin upregulation and dysfunction of tight junctions in both $\mathrm{CeD}$ and T1D [19]. T1D is characterized by the infiltration of the pancreatic islets by lymphocytes and macrophages, the presence of autoantibodies to islet cell antigens (ICA), tyrosine phosphatase (IA2), glutamic acid decarboxylase-65 (GAD), insulin (IAA), and zinc transporter ZnT8 (Slc30A8), an increased prevalence of organ-specific autoimmune disorders in T1D, a preferential occurrence of T1D in persons carrying specific allelic combinations at immune response loci within the HLA gene complex. The disease can be transferred by spleen or bone marrow cells and animal models of T1D show a defect in immunoregulation contributing to the onset of disease [20].

\subsection{Hashimoto's Thyroiditis}

HT is currently the most common autoimmune disease and frequently clusters with other autoimmune endocrinopathies. It is defined by the presence of thyro-peroxidase (TPO) or thyroglobulin (Tg) Ab and either normal or elevated serum thyroid stimulating hormone (TSH) concentrations. The majority of patients with HT are hypothyroid; however there is a subgroup of thyroid Ab-positive cases who are euthyroid. HT frequently occurs with T1D, with a prevalence of $13-20 \%$ of subclinical hypothyroidism in T1D patients compared with 3-6\% in a non-diabetic population. Overt hypothyroidism is present in $4-18 \%$ of subjects with T1D. TPO-Ab are present in $15-30 \%$ of adults and in $5-22 \%$ of children with T1D, compared with $2-10 \%$ and $1-4 \%$, respectively, in healthy controls. Up to $50 \%$ of TPO-Ab positive T1D patients progress to overt AITD. As many as $30 \%$ of patients with T1D develop AITD. Age, duration of T1D, and female preponderance impact the link between T1D and AITD [21,22]. In a prospective controlled study, celiac patients had an increased risk of thyroid autoimmune disorders when compared to non-celiac controls on normal gluten-containing diet [23]. However, in this Scandinavian trial, a gluten-free diet seemed not to prevent the progression of autoimmune process during a follow-up of one year.

\subsection{Graves' Disease}

GD is meanwhile less prevalent than HT; it affects approximately 1-1.5\% of the general population worldwide and is the underlying cause of $50-80 \%$ of cases of thyrotoxicosis. GD and HT share many immunological features, including high serum concentrations of Ab against Tg and TPO. GD is caused by TSH receptor stimulating $\mathrm{Ab}$ [24-26] that bind to and activate the TSH receptor on thyroid cells. These $\mathrm{Ab}$ not only cause hypersecretion of thyroid hormone, but also promote hypertrophy and hyperplasia of thyroid follicles, resulting in an enhanced vascularization of the gland and in a diffuse goiter. Women are five to ten times more at risk of developing GD than men, due to the relevant involvement of sex hormones. Also, stress and negative life events are regarded as risk factors for GD and may trigger the disease. Subclinical endogeneous hyperthyroidism can be diagnosed in $6-10 \%$ of T1D patients, compared with $0.1-2 \%$ in the non-diabetic population. The incidence of overt autoimmune hyperthyroidism in persons with a suppressed serum TSH is calculated at $2-4 \%$ per year [27].

\subsection{Polyglandular Autoimmune Syndrome}

The association of two or more glandular autoimmune diseases is designated as PAS. Especially in adults, the presence of one autoimmune endocrine disorder increases the risk of developing other autoimmune diseases. $\mathrm{CeD}$ is a strong predictor not only of glandular but also polyglandular autoimmunity. PAS shows a great heterogeneity of syndromes and usually manifests sequentially, with a variable time interval between the occurrence of the first and second glandular autoimmune disease component. It also clusters with several non-endocrine autoimmune diseases [28]. PAS is divided into two major subtypes, which are distinguished according to age of presentation, characteristic patterns of disease combinations and different modes of inheritance. Juvenile PAS I, also known as autoimmune polyendocrinopathy-candidiasis-ectodermal dystrophy, usually manifests in infancy or childhood 
at age three to five years, or in early adolescence, It is characterized by a persistent fungal infection (chronic mucocutaneous candidiasis), the presence of acquired hypoparathyroidism and adrenal failure. In most patients mucocutaneous candidiasis precedes the other immune disorders, usually followed by hypoparathyroidism. The female-to-male ratio varies from 0.8:1 to 2.4:1. The highest prevalence of PAS I has been found in populations characterized by a high degree of consanguinity or descendants of small founder populations, particularly in Iranian Jews and Fins. PAS I is a monogenic disease with autosomal recessive inheritance caused by mutations in the autoimmune regulatory gene (AIRE) on chromosome 21. Adult PAS occurs mainly in the third or fourth decade. Adult PAS subtype II encompasses adrenal failure or Addison's disease (AD) with other autoimmune endocrine disorders, i.e., AITD and/or T1D. AD may precede other endocrinopathies. In contrast to the juvenile type, family members of adult PAS II patients are often affected. PAS II is believed to be polygenic, characterized by autosomal dominant inheritance [29-34].

The adult PAS type III is the most frequent PAS type and is characterized by AITD and T1D and the absence of AD. In contrast, the poorly defined PAS type IV is very heterogeneous involving a large variety of glandular autoimmune diseases that are not considered within adult PAS types 2 and 3. Being less well defined, it is often incorrectly described as a combination of monoglandular autoimmune disease with one non-glandular autoimmune disease. In fact, PAS type IV includes various combinations of autoimmune hypopituitarism, hypergonadotropic hypogonadism, or hypoparathyroidism with T1D or an AITD. The adult form of PAS has a prevalence of 1:20,000, and is far more prevalent than the juvenile type, with an annual incidence of 1-2:100,000. The gender ratio of adult PAS types II-IV shows a female predominance of $75 \%$ [35,36]. The manifestation peaks in the fourth and fifth decade depending on the combination of the various autoimmune endocrinopathies [37].

Even if the time between the manifestations of $\mathrm{CeD}$ and other autoimmune endocrinopathies, as well as the time until a PAS can be diagnosed, is highly variable, many patients with one autoimmune disease already have Ab against other, often endocrine, tissues (Table 2). The reason is the tendency of autoimmune diseases to associate with one another, especially when they share a genetic basis, of the metachronous manifestations of the component diseases, and of the often subclinical initial course. Mainly first but also second degree family members of patients are often at risk for developing related autoimmunities and are already $\mathrm{Ab}$ positive.

Table 2. Prevalence of autoimmune thyroid disease auto-antibodies in patients with celiac disease.

\begin{tabular}{cccc}
\hline CeD Patients Studied $(N)$ & $\begin{array}{c}\text { Prevalence of Thyroid } \\
\text { Autoantibodies, } \boldsymbol{N}\end{array}$ & $\begin{array}{c}\text { Prevalence of Thyroid } \\
\text { Autoantibodies in \% }\end{array}$ & Reference \\
\hline \multirow{2}{*}{107} & Tg Ab, $N=12$ & 11.2 & {$[38]$} \\
70 & TMA, $N=16$ & 15 & {$[39]$} \\
47 & TMA, $N=15$ & 21 & {$[40]$} \\
& TPO, $N=14$ & 29.7 & {$[41]$} \\
34 & TMA, $N=5$ & 32.4 & \\
& Tg Ab, $N=11$ & 11.8 & {$[42]$} \\
30 & TPO, $N=4$ & 14.4 & {$[43]$} \\
\hline
\end{tabular}

Modified according to reference [44]. CeD: celiac disease, Tg-Ab: thyroglobulin antibodies; TMA: thyroid microsomal antibodies; TPO-Ab: thyro-peroxidase antibodies.

\section{The Role of a Gluten Free Diet in Preventing Celiac Disease and Glandular Autoimmunity}

A large prospective study demonstrated that in infants at genetic risk for $\mathrm{CeD}$ and T1D (i.e., from families with at least one affected parent and the $D R 3 / D Q 2$ and/or $D R 4 / D Q 8$ risk genes) a careful early introduction of $100 \mathrm{mg}$ gluten per day in the diet from month 5-6 did not prevent celiac autoimmunity compared to placebo [45]. Moreover, the introduction of gluten at 12 instead of 6 
months of age only delayed the onset of $\mathrm{CeD}$, with similar prevalences at age 5 years [46]. However, a retrospective study indicated that patients on a long-term gluten free diet developed $50 \%$ fewer autoimmune diseases in up to 15 years of follow up [47]. The (retrospective) studies that examined the effect of a gluten free versus gluten containing diet on the development and severity of T1D and AITD remain controversial (Tables 3 and 4). Interestingly, T1D appears to precede the development of CeD, as determined by IgA-TG2 Ab positivity, which would assign a less important role to the gluten free diet in the prevention of glandular autoimmunity [19].

Table 3. Gluten exposure and occurrence of type 1 diabetes.

\begin{tabular}{ccccc}
\hline Patients $(\boldsymbol{N})$ & $\begin{array}{c}\text { Duration of } \\
\text { Follow-up (Years) }\end{array}$ & $\begin{array}{c}\text { Early CeD Dx } \\
\text { Protective? }\end{array}$ & GFD Protective? & Reference \\
\hline 90 & 2 & NE & Yes & {$[42]$} \\
44 & 1.6 & No & Yes & {$[48]$} \\
383 & 7.6 & No & NE & {$[49]$} \\
1183 & 0.9 & NE & Yes & {$[50]$} \\
19796 & NE & No & NE & {$[51]$} \\
4322 & NE & No & NE & {$[52]$} \\
150 & 3 & NE & Yes & {$[53]$} \\
\hline
\end{tabular}

Table 4. Gluten exposure and occurrence of autoimmune thyroid disease (AITD).

\begin{tabular}{ccccc}
\hline Patients $(\boldsymbol{N})$ & $\begin{array}{c}\text { Duration of } \\
\text { Follow-up (Years) }\end{array}$ & $\begin{array}{c}\text { Early CeD Dx } \\
\text { Protective? }\end{array}$ & GFD Protective? & Reference \\
\hline 909 & $>0.5$ & Yes & NE & {$[42]$} \\
44 & 1.6 & No & Yes & {$[48]$} \\
66 & $1-5$ & Yes & Yes & {$[54]$} \\
343 & $0.25-16$ & NE & No & {$[55]$} \\
324 & 8 & Yes & No & {$[56]$} \\
135 & 8.9 & No & No & {$[57]$} \\
545 & 2 & No & No & {$[58]$} \\
335 & 9 & No & No & {$[59]$} \\
\hline
\end{tabular}

Dx: diagnosis; GFD: gluten free diet; NE: not evaluated.

Several mainly retrospective and correlative studies, often based on registries, have tried to address the question, how far an early diagnosis of $\mathrm{CeD}$ and/or a gluten free diet may protect from AITD or T1D. As shown in tables 3 and 4, in these studies early diagnosis of CeD did not appear to protect from the development of T1D [42,48-53]; whereas some studies suggested such protection in AITD [42,48,54-59]. In comparison, a gluten free diet (GFD) may positively impact the occurrence of T1D rather than of AITD. These somewhat conflicting data need validation in large, prospective studies with well-defined diagnosis and markers of CeD, T1D, and AITD. Such studies are currently performed in children with an increased risk for the three diseases (being offspring of affected parents and carrying the $D Q 2$ and / or $D Q 8$ genes. However, a beneficial effect of a gluten free diet may be expected, since in general, in children as well as in adults, intestinal inflammation and the associated dysbiosis, with or without underlying $\mathrm{CeD}$, are known to promote extra intestinal autoimmune diseases [60-62]. Therefore, any measure that would dampen gut inflammation in CeD patients will likely positively impact the evolution and perhaps the manifestation of glandular autoimmunity.

Author Contributions: G.J.K., L.F., and D.S. jointly drafted and edited the article.

Funding: D.S. receives CeD related funding form the German Research Foundation (DFG 646/17-1).

Acknowledgments: The authors are grateful to Tanja Diana, Elisa Schulze, and Marie Kuschnereit, JGU Thyroid Research Lab, Mainz, Germany for data collection.

Conflicts of Interest: The authors declare no conflict of interest. 


\section{References}

1. Schuppan, D.; Junker, Y.; Barisani, D. Celiac disease: From pathogenesis to novel therapies. Gastroenterology 2009, 137, 1912-1933. [CrossRef] [PubMed]

2. Fasano, A.; Catassi, C. Clinical practice. Celiac disease. N. Engl. J. Med. 2012, 367, 2419-2426. [CrossRef] [PubMed]

3. Sollid, L.M.; Jabri, B. Triggers and drivers of autoimmunity: Lessons from coeliac disease. Nat. Rev. Immunol. 2013, 13, 294-302. [CrossRef] [PubMed]

4. Lundin, K.E.; Sollid, L.M. Advances in coeliac disease. Curr. Opin. Gastroenterol. 2014, 30, 154-162. [CrossRef] [PubMed]

5. Ventura, A.; Magazzu, G.; Greco, L. Duration of exposure to gluten and risk for autoimmune disorders in patients with celiac disease. Sigep study group for autoimmune disorders in celiac disease. Gastroenterology 1999, 117, 297-303. [CrossRef] [PubMed]

6. Malamut, G.; Meresse, B.; Cellier, C.; Cerf-Bensussan, N. Refractory celiac disease: From bench to bedside. Semin. Immunopathol. 2012, 34, 601-613. [CrossRef] [PubMed]

7. Van Gils, T.; Nijeboer, P.; van Wanrooij, R.L.; Bouma, G.; Mulder, C.J. Mechanisms and management of refractory coeliac disease. Nat. Rev. Gastroenterol. Hepatol. 2015, 12, 572-579. [CrossRef] [PubMed]

8. Pham-Short, A.; Donaghue, K.C.; Ambler, G.; Garnett, S.; Craig, M.E. Greater postprandial glucose excursions and inadequate nutrient intake in youth with type 1 diabetes and celiac disease. Sci. Rep. 2017, 7, 45286. [CrossRef] [PubMed]

9. Vazquez, H.; de la Paz Temprano, M.; Sugai, E.; Scacchi, S.M.; Souza, C.; Cisterna, D.; Smecuol, E.; Moreno, M.L.; Longarini, G.; Mazure, R.; et al. Prevalence of celiac disease and celiac autoimmunity in the toba native amerindian community of Argentina. Can. J. Gastroenterol. Hepatol. 2015, 29, 431-434. [CrossRef] [PubMed]

10. Dieterich, W.; Ehnis, T.; Bauer, M.; Donner, P.; Volta, U.; Riecken, E.O.; Schuppan, D. Identification of tissue transglutaminase as the autoantigen of celiac disease. Nat. Med. 1997, 3, 797-801. [CrossRef] [PubMed]

11. Molberg, O.; McAdam, S.N.; Korner, R.; Quarsten, H.; Kristiansen, C.; Madsen, L.; Fugger, L.; Scott, H.; Noren, O.; Roepstorff, P.; et al. Tissue transglutaminase selectively modifies gliadin peptides that are recognized by gut-derived $t$ cells in celiac disease. Nat. Med. 1998, 4, 713-717. [CrossRef] [PubMed]

12. Van de Wal, Y.; Kooy, Y.M.; van Veelen, P.A.; Pena, S.A.; Mearin, L.M.; Molberg, O.; Lundin, K.E.; Sollid, L.M.; Mutis, T.; Benckhuijsen, W.E.; et al. Small intestinal T cells of celiac disease patients recognize a natural pepsin fragment of gliadin. Proc. Natl. Acad. Sci. USA 1998, 95, 10050-10054. [CrossRef] [PubMed]

13. Frohlich-Reiterer, E.E.; Hofer, S.; Kaspers, S.; Herbst, A.; Kordonouri, O.; Schwarz, H.P.; Schober, E.; Grabert, M.; Holl, R.W.; Group, D.P.-W.S. Screening frequency for celiac disease and autoimmune thyroiditis in children and adolescents with type 1 diabetes mellitus-Data from a German/Austrian multicentre survey. Pediatr. Diabetes 2008, 9, 546-553. [CrossRef] [PubMed]

14. Boelaert, K.; Newby, P.R.; Simmonds, M.J.; Holder, R.L.; Carr-Smith, J.D.; Heward, J.M.; Manji, N.; Allahabadia, A.; Armitage, M.; Chatterjee, K.V.; et al. Prevalence and relative risk of other autoimmune diseases in subjects with autoimmune thyroid disease. Am. J. Med. 2010, 123, e181-e189. [CrossRef] [PubMed]

15. Dittmar, M.; Libich, C.; Brenzel, T.; Kahaly, G.J. Increased familial clustering of autoimmune thyroid diseases. Horm. Metab. Res. 2011, 43, 200-204. [CrossRef] [PubMed]

16. Villano, M.J.; Huber, A.K.; Greenberg, D.A.; Golden, B.K.; Concepcion, E.; Tomer, Y. Autoimmune thyroiditis and diabetes: Dissecting the joint genetic susceptibility in a large cohort of multiplex families. J Clin. Endocrinol. Metab. 2009, 94, 1458-1466. [CrossRef] [PubMed]

17. Kahaly, G.J.; Schuppan, D. Celiac disease and endocrine autoimmunity. Dig. Dis. 2015, 33, $155-161$. [CrossRef] [PubMed]

18. Kordonouri, O.; Dieterich, W.; Schuppan, D.; Webert, G.; Muller, C.; Sarioglu, N.; Becker, M.; Danne, T. Autoantibodies to tissue transglutaminase are sensitive serological parameters for detecting silent coeliac disease in patients with type 1 diabetes mellitus. Diabet. Med. 2000, 17, 441-444. [CrossRef] [PubMed]

19. Hagopian, W.; Lee, H.S.; Liu, E.; Rewers, M.; She, J.X.; Ziegler, A.G.; Lernmark, A.; Toppari, J.; Rich, S.S.; Krischer, J.P.; et al. Co-occurrence of type 1 diabetes and celiac disease autoimmunity. Pediatrics 2017, 140. [CrossRef] [PubMed] 
20. Kahaly, G.J.; Hansen, M.P. Type 1 diabetes associated autoimmunity. Autoimmun. Rev. 2016, 15, 644-648. [CrossRef] [PubMed]

21. Ponto, K.A.; Schuppan, D.; Zwiener, I.; Binder, H.; Mirshahi, A.; Diana, T.; Pitz, S.; Pfeiffer, N.; Kahaly, G.J. Thyroid-associated orbitopathy is linked to gastrointestinal autoimmunity. Clin. Exp. Immunol. 2014, 178, 57-64. [CrossRef] [PubMed]

22. Schuppan, D.; Ciccocioppo, R. Coeliac disease and secondary autoimmunity. Dig. Liver. Dis. 2002, 34, $13-15$. [CrossRef]

23. Metso, S.; Hyytia-Ilmonen, H.; Kaukinen, K.; Huhtala, H.; Jaatinen, P.; Salmi, J.; Taurio, J.; Collin, P. Gluten-free diet and autoimmune thyroiditis in patients with celiac disease. A prospective controlled study. Scand. J. Gastroenterol. 2012, 47, 43-48. [CrossRef] [PubMed]

24. Diana, T.; Wuster, C.; Olivo, P.D.; Unterrainer, A.; Konig, J.; Kanitz, M.; Bossowski, A.; Decallonne, B.; Kahaly, G.J. Performance and specificity of 6 immunoassays for TSH receptor antibodies: A multicenter study. Eur. Thyroid. J. 2017, 6, 243-249. [CrossRef] [PubMed]

25. Diana, T.; Wuster, C.; Kanitz, M.; Kahaly, G.J. Highly variable sensitivity of five binding and two bio-assays for TSH-receptor antibodies. J. Endocrinol. Invest. 2016, 39, 1159-1165. [CrossRef] [PubMed]

26. Diana, T.; Brown, R.S.; Bossowski, A.; Segni, M.; Niedziela, M.; Konig, J.; Bossowska, A.; Ziora, K.; Hale, A.; Smith, J.; et al. Clinical relevance of thyroid-stimulating autoantibodies in pediatric graves' disease-A multicenter study. J. Clin. Endocrinol. Metab. 2014, 99, 1648-1655. [CrossRef] [PubMed]

27. Ross, D.S.; Burch, H.B.; Cooper, D.S.; Greenlee, M.C.; Laurberg, P.; Maia, A.L.; Rivkees, S.A.; Samuels, M.; Sosa, J.A.; Stan, M.N.; et al. 2016 American thyroid association guidelines for diagnosis and management of hyperthyroidism and other causes of thyrotoxicosis. Thyroid 2016, 26, 1343-1421. [CrossRef] [PubMed]

28. Kahaly, G.J.; Frommer, L. Polyglandular autoimmune syndromes. J. Endocrinol. Invest. 2018, 41, 91-98. [CrossRef] [PubMed]

29. Kahaly, G.J. Polyglandular autoimmune syndromes. Eur. J. Endocrinol. 2009, 161, 11-20. [CrossRef] [PubMed]

30. Dittmar, M.; Kahaly, G.J. Polyglandular autoimmune syndromes: Immunogenetics and long-term follow-up. J. Clin. Endocrinol. Metab. 2003, 88, 2983-2992. [CrossRef] [PubMed]

31. Weinstock, C.; Matheis, N.; Barkia, S.; Haager, M.C.; Janson, A.; Markovic, A.; Bux, J.; Kahaly, G.J. Autoimmune polyglandular syndrome type 2 shows the same HLA class ii pattern as type 1 diabetes. Tissue Antigens 2011, 77, 317-324. [CrossRef] [PubMed]

32. Selmi, C. Autoimmunity in 2011. Clin. Rev. Allergy Immunol. 2012, 43, 194-206. [CrossRef] [PubMed]

33. Anaya, J.M. The diagnosis and clinical significance of polyautoimmunity. Autoimmun. Rev. 2014, 13, 423-426. [CrossRef] [PubMed]

34. Cutolo, M. Autoimmune polyendocrine syndromes. Autoimmun. Rev. 2014, 13, 85-89. [CrossRef] [PubMed]

35. Betterle, C.; Zanchetta, R. Update on autoimmune polyendocrine syndromes (aps). Acta. Biomed. 2003, 74, 9-33. [PubMed]

36. Betterle, C.; Lazzarotto, F.; Presotto, F. Autoimmune polyglandular syndrome type 2: The tip of an iceberg? Clin. Exp. Immunol. 2004, 137, 225-233. [CrossRef] [PubMed]

37. Houcken, J.; Degenhart, C.; Bender, K.; Konig, J.; Frommer, L.; Kahaly, G.J. PTPN22 and CTLA-4 polymorphisms are associated with polyglandular autoimmunity. J. Clin. Endocrinol. Metab. 2018. [CrossRef] [PubMed]

38. Counsell, C.E.; Taha, A.; Ruddell, W.S. Coeliac disease and autoimmune thyroid disease. Gut 1994, 35, 844-846. [CrossRef] [PubMed]

39. Volta, U.; de Franceschi, L.; Molinaro, N.; Tetta, C.; Bianchi, F.B. Organ-specific autoantibodies in coeliac disease: Do they represent an epiphenomenon or the expression of associated autoimmune disorders? Ital. J. Gastroenterol. Hepatol. 1997, 29, 18-21. [PubMed]

40. Velluzzi, F.; Caradonna, A.; Boy, M.F.; Pinna, M.A.; Cabula, R.; Lai, M.A.; Piras, E.; Corda, G.; Mossa, P.; Atzeni, F.; et al. Thyroid and celiac disease: Clinical, serological, and echographic study. Am. J. Gastroenterol. 1998, 93, 976-979. [CrossRef] [PubMed]

41. Kowalska, E.; Wasowska-Krolikowska, K.; Toporowska-Kowalska, E. Estimation of antithyroid antibodies occurrence in children with coeliac disease. Med. Sci. Monit. 2000, 6, 719-721. [PubMed]

42. Ventura, A.; Neri, E.; Ughi, C.; Leopaldi, A.; Citta, A.; Not, T. Gluten-dependent diabetes-related and thyroid-related autoantibodies in patients with celiac disease. J. Pediatr. 2000, 137, 263-265. [CrossRef] [PubMed] 
43. Carta, M.G.; Hardoy, M.C.; Boi, M.F.; Mariotti, S.; Carpiniello, B.; Usai, P. Association between panic disorder, major depressive disorder and celiac disease: A possible role of thyroid autoimmunity. J. Psychosom. Res. 2002, 53, 789-793. [CrossRef]

44. Ch'ng, C.L.; Jones, M.K.; Kingham, J.G. Celiac disease and autoimmune thyroid disease. Clin. Med. Res. 2007, 5, 184-192. [CrossRef] [PubMed]

45. Vriezinga, S.L.; Auricchio, R.; Bravi, E.; Castillejo, G.; Chmielewska, A.; Crespo Escobar, P.; Kolacek, S.; Koletzko, S.; Korponay-Szabo, I.R.; Mummert, E.; et al. Randomized feeding intervention in infants at high risk for celiac disease. N. Engl. J. Med. 2014, 371, 1304-1315. [CrossRef] [PubMed]

46. Lionetti, E.; Castellaneta, S.; Francavilla, R.; Pulvirenti, A.; Tonutti, E.; Amarri, S.; Barbato, M.; Barbera, C.; Barera, G.; Bellantoni, A.; et al. Introduction of gluten, HLA status, and the risk of celiac disease in children. N. Engl. J. Med. 2014, 371, 1295-1303. [CrossRef] [PubMed]

47. Cosnes, J.; Cellier, C.; Viola, S.; Colombel, J.F.; Michaud, L.; Sarles, J.; Hugot, J.P.; Ginies, J.L.; Dabadie, A.; Mouterde, O.; et al. Incidence of autoimmune diseases in celiac disease: Protective effect of the gluten-free diet. Clin. Gastroenterol. Hepatol. 2008, 6, 753-758. [CrossRef] [PubMed]

48. Toscano, V.; Conti, F.G.; Anastasi, E.; Mariani, P.; Tiberti, C.; Poggi, M.; Montuori, M.; Monti, S.; Laureti, S.; Cipolletta, E.; et al. Importance of gluten in the induction of endocrine autoantibodies and organ dysfunction in adolescent celiac patients. Am. J. Gastroenterol. 2000, 95, 1742-1748. [CrossRef] [PubMed]

49. Valerio, G.; Maiuri, L.; Troncone, R.; Buono, P.; Lombardi, F.; Palmieri, R.; Franzese, A. Severe clinical onset of diabetes and increased prevalence of other autoimmune diseases in children with coeliac disease diagnosed before diabetes mellitus. Diabetologia 2002, 45, 1719-1722. [PubMed]

50. Norris, J.M.; Barriga, K.; Hoffenberg, E.J.; Taki, I.; Miao, D.; Haas, J.E.; Emery, L.M.; Sokol, R.J.; Erlich, H.A.; Eisenbarth, G.S.; et al. Risk of celiac disease autoimmunity and timing of gluten introduction in the diet of infants at increased risk of disease. JAMA 2005, 293, 2343-2351. [CrossRef] [PubMed]

51. Kaspers, S.; Kordonouri, O.; Schober, E.; Grabert, M.; Hauffa, B.P.; Holl, R.W. Anthropometry, metabolic control, and thyroid autoimmunity in type 1 diabetes with celiac disease: A multicenter survey. J. Pediatr. 2004, 145, 790-795. [CrossRef] [PubMed]

52. Cerutti, F.; Bruno, G.; Chiarelli, F.; Lorini, R.; Meschi, F.; Sacchetti, C.; the Diabetes Study Group of Italian Society of Pediatric Endocrinology and Diabetology. Younger age at onset and sex predict celiac disease in children and adolescents with type 1 diabetes: An Italian multicenter study. Diabetes Care 2004, 27, 1294-1298. [CrossRef] [PubMed]

53. Hummel, S.; Pfluger, M.; Hummel, M.; Bonifacio, E.; Ziegler, A.G. Primary dietary intervention study to reduce the risk of islet autoimmunity in children at increased risk for type 1 diabetes: The babydiet study. Diabetes Care 2011, 34, 1301-1305. [CrossRef] [PubMed]

54. Oderda, G.; Rapa, A.; Zavallone, A.; Strigini, L.; Bona, G. Thyroid autoimmunity in childhood celiac disease. J. Pediatr. Gastroenterol. Nutr. 2002, 35, 704-705. [CrossRef] [PubMed]

55. Ansaldi, N.; Palmas, T.; Corrias, A.; Barbato, M.; D'Altiglia, M.R.; Campanozzi, A.; Baldassarre, M.; Rea, F.; Pluvio, R.; Bonamico, M.; et al. Autoimmune thyroid disease and celiac disease in children. J. Pediatr. Gastroenterol. Nutr. 2003, 37, 63-66. [CrossRef] [PubMed]

56. Meloni, A.; Mandas, C.; Jores, R.D.; Congia, M. Prevalence of autoimmune thyroiditis in children with celiac disease and effect of gluten withdrawal. J. Pediatr. 2009, 155, 51-55. [CrossRef] [PubMed]

57. Cassio, A.; Ricci, G.; Baronio, F.; Miniaci, A.; Bal, M.; Bigucci, B.; Conti, V.; Cicognani, A. Long-term clinical significance of thyroid autoimmunity in children with celiac disease. J. Pediatr. 2010, 156, 292-295. [CrossRef] [PubMed]

58. Diamanti, A.; Ferretti, F.; Guglielmi, R.; Panetta, F.; Colistro, F.; Cappa, M.; Daniele, A.; Sole Basso, M.; Noto, C.; Crisogianni, M.; et al. Thyroid autoimmunity in children with coeliac disease: A prospective survey. Arch. Dis. Child. 2011, 96, 1038-1041. [CrossRef] [PubMed]

59. Van der Pals, M.; Ivarsson, A.; Norstrom, F.; Hogberg, L.; Svensson, J.; Carlsson, A. Prevalence of thyroid autoimmunity in children with celiac disease compared to healthy 12-year olds. Autoimmune Dis. 2014, 2014, 417356. [CrossRef] [PubMed]

60. Li, C.; Xu, M.M.; Wang, K.; Adler, A.J.; Vella, A.T.; Zhou, B. Macrophage polarization and meta-inflammation. Transl. Res. 2018, 191, 29-44. [CrossRef] [PubMed]

61. De Oliveira, G.L.V.; Leite, A.Z.; Higuchi, B.S.; Gonzaga, M.I.; Mariano, V.S. Intestinal dysbiosis and probiotic applications in autoimmune diseases. Immunology 2017, 152, 1-12. [CrossRef] [PubMed] 
62. Thaiss, C.A.; Zmora, N.; Levy, M.; Elinav, E. The microbiome and innate immunity. Nature 2016, 535, 65-74. [CrossRef] [PubMed] 